\title{
公 衆衛生
}

神奈川県下に飼養されているサルの糞便検査成績

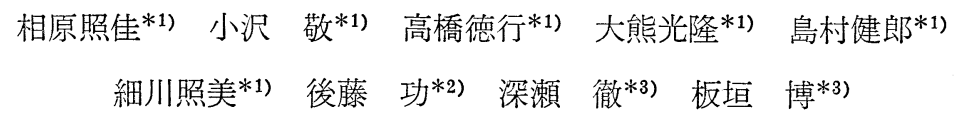

(昭和 58 年 11 月 18 日受理)

\begin{abstract}
Trichuris and Strongyloides Detected from Feces of Monkeys Kept in Kanagawa Prefecture

Teruyoshi Ainara (Animal Protection Center, Prefecture of Kanagawa, Hiratsuka, Kanagawa 259-12) et al.
\end{abstract}

\section{SUMMARY}

The Feces of 74 monkeys kept in Kanagawa Prefecture were examined in July and August, 1982. Shigella or Salmonella was not detected at all. Whipworms and/or intestinal threadworms were found in one of 24 monkeys kept individually as pet animals and in 5 of 6 sites where monkeys were kept for exhibition. They were identified as Trichuris trichiura and Strongyloides fülleborni, respectively. These species were of public health significance.

要約

1982 年 7 月 8 月に, 横浜市・川崎市・横須賀市を除く神奈川県下の 22 力所飞飼養されている サル 74 頭（愛玩用個別飼養 : 16 力所 24 頭, 展示用群飼養 : 6 力所 50 頭）飞ついて, Shigella, Salmonella 和よび寄生蠕虫類を対象とした䔬便検查を行った。 その結果, Shigella おょび Salmonella はまったく検出されなかったが，個別飼養されているサル 24 頭のらちの 1 頭浭鞭虫と䔬線虫 の混合感染がみられ, また, 群飼養されている 6 群では 5 群に鞭虫, 4 群に萯線虫（4 群は両種の 混合感染）が認められた。これらの鞭虫は Trichuris trichiura，蕒線虫は Strongyloides fülleborni 之 考光られる. T. trichiura は人体寄生の鞭虫と同一種であり，S. filleborni も人体に寄生することが 知られているので, サル類の飼養管理にあたっては十分な注意が必要である.とくに, 観覽者のた めの展示用として飼養されているサルに高率にこれらの寄生虫の感染が認められたことは, 公衆衛 生上の問題が大きいと思われる.

人畜共通感染症の人体への感染源としては種々の動物 が考光られるが，とくに，飼養されている動物について は，人間の生活と密着していることから，十分に注意す る必要がある. 近年, 好みの多様化にともなって多種多 様な動物が一般に飼養されるよらになってきているが, これらの飼養動物のうちでも, サル類は, 動物分類学的 にヒトに近いところから，その病原体も人間と共通なる のが多く，きわめて重要であると考光られる.

輸入サル類に括いては, 赤痢菌やサルモネラなどの病

*1) 神奈川県動物保護センター（神奈川県平塚市土屋 401)

*2) 神奈川県茅ヶ崎保健所(神奈川県茅ヶ崎市矢畑 910 -1)

*3) 麻布大学獣医学部（神奈川県相模原市淵野辺 1-17 $-71)$
原性細菌 ${ }^{3,4,19,23)}$ や各種の寄生虫 ${ }^{1,5,10,11,13)}$ の感染が濃厚 飞存在していることが知られており, 公衆衛生上の問題 が指摘されている.これに対し,すで飼養されているサ ル類については，その飼養実態も不明瞭であったことな どから, 一部の動物園7,9,15) や日本モンキーセンター2,14) などを除いては，ほとんど調査が行われていないようで ある. そこで, 今回, 横浜市・川崎市・横須賀市を除く 神奈川県下に特政るサルの飼養状沉が神奈川県動物保護 管理条例の下に括いて明確となったのを機会に, この地 域に飼養されているサル類について, Shigella, Salmonella 抒よび寄生蠕虫類の感染状況の調査を実施した.

\section{1. 材料および方法}

\section{1）調 查 対 象と 期 間}

横浜市・川崎市・横須賀市を除く神奈川県下の 22 カ 
相原照佳 小沢 敬 高橋德行 大熊光隆島村健郎 細川照美後藤 功樑瀬徹 板垣 博

所に飼養されているサル 74 頭を調査の対象とした。こ の 22 力所 74 頭のうち, 16 力所は愛玩用として個別に 飼養されている 24 頭であり，6カ所は観覧者への展示 用に 3〜16 頭の群として飼養されている 50 頭である. これらのサルの地区ごとの飼養頭数と種類・年龄などを, それぞれ表 1 和よび表 2 に示す。

群飼養されているものについて䔬便の検査を実施する 飞あたっては，個体別に䔬便を採取することが不可能で めったので，各群ごとにそれぞれ 3〜8検体を採取して， そのらちの 1 検体でも陽性であればその群は陽性とし， 群ごとに陽性・陰性そ判定した。

な抒，調查は 1982 年 7 月〜8 月汇実施した。

\section{2) 細 菌 検 査}

細菌培養用の糞便（1 検体注き 3〜 $5 \mathrm{~g}$ ) は, CARY \& BLAIR の輸送培地飞移して輪送し，検查するまで $4{ }^{\circ} \mathrm{C} に$

表 1 サルの市町村別飼湌状沉

（1982年6月30日現在）

\begin{tabular}{|c|c|c|c|c|}
\hline 市 & 町 & 村 & 飼養力所 & 飼盖頭数 \\
\hline 平 & 塚 & 市 & 2 & 2 \\
\hline 鎌 & 倉 & 市 & 2 & 2 \\
\hline 逗 & 子 & 市 & 1 & 16 \\
\hline 葉 & 山 & 市 & 1 & 1 \\
\hline 藤 & 沢 & 市 & 1 & 1 \\
\hline 小 & 田＼cjkstart原 & 市 & 2 & 9 \\
\hline 箱 & 根 & 町 & 1 & 3 \\
\hline 真 & 鶴 & 町 & 1 & 12 \\
\hline 茅 & ケ椅 & 市 & 1 & 1 \\
\hline 寒 & 川 & 町 & 1 & 2 \\
\hline 相 & 模＼cjkstart原 & 市 & 1 & 1 \\
\hline 伊 & 勢 原 & 市 & 2 & 3 \\
\hline 厚 & 木 & 市 & 3 & 10 \\
\hline 棱 & 瀬 & 市 & 1 & 1 \\
\hline 藤 & 野 & 町 & 1 & 3 \\
\hline 相 & 模 湖 & 町 & 1 & 7 \\
\hline & 計 & & 22 & 74 \\
\hline
\end{tabular}

保存した。Shigella の分離は，検体を白金耳で SS 寒天

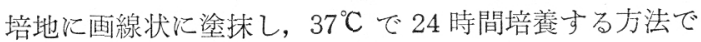
行った。 また, Salmonella の分離は, 検体約 $1 \mathrm{~g}$ 学 10 $\mathrm{ml}$ の HajNa \& Damon のテトラチオン酸塩培地傜植 し， $37^{\circ} \mathrm{C}$ で 24 時間培養して増菌した後に，その 1 白金 耳它 SS 寒天培地特よびブリリアントグリーン寒天培地

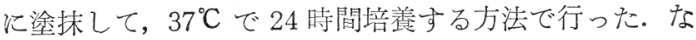
お，疑方乙い集落が登育した場合には，TSI 培地，SIM 培地，リジン脱炭酸試験培地括よび VP 半流動培地を用 い, その生化学的性状を検雀した。

\section{3）蠕 虫 検 査}

䔬便内虫卵検查以直接塗抹法, 飽和食塩液浮遊法, 特 よびホルマリン・エーテル法（MGL 法）により行い， 虫卵の培養は濾紙培養法により行った。亦た, 寄生虫の 感染が認められたサルの一部については, 剖検を実施し， 虫体を採取した。

\section{2. 成績}

\section{1)細菌検査成 續}

調査したすべてのサルの翼便から Shigella 趽よび SaImonella はまったく検出されなかった。

\section{2）蠕 虫検 査 成 績}

愛玩用として個別に飼荃されている 24 頭のうらの 1 頭（カニクイザル）の粪便から, 直接塗抹法, 飽和食塩 液浮遊法, MGL 法により, 鞭虫卵と子虫を含先線虫卵

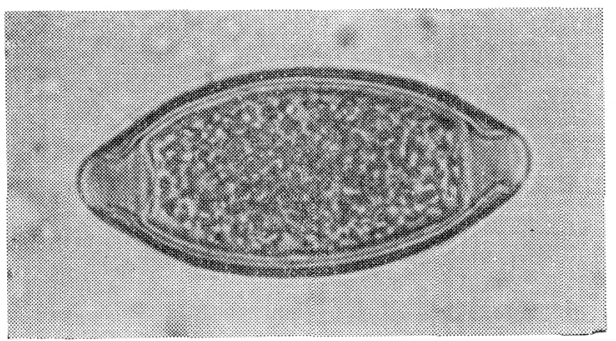

写真 1 鞭 虫 即 表 2 サルの種 類 - 性・年 齡 別 飼 養状況 (1982 年6月30日現在)

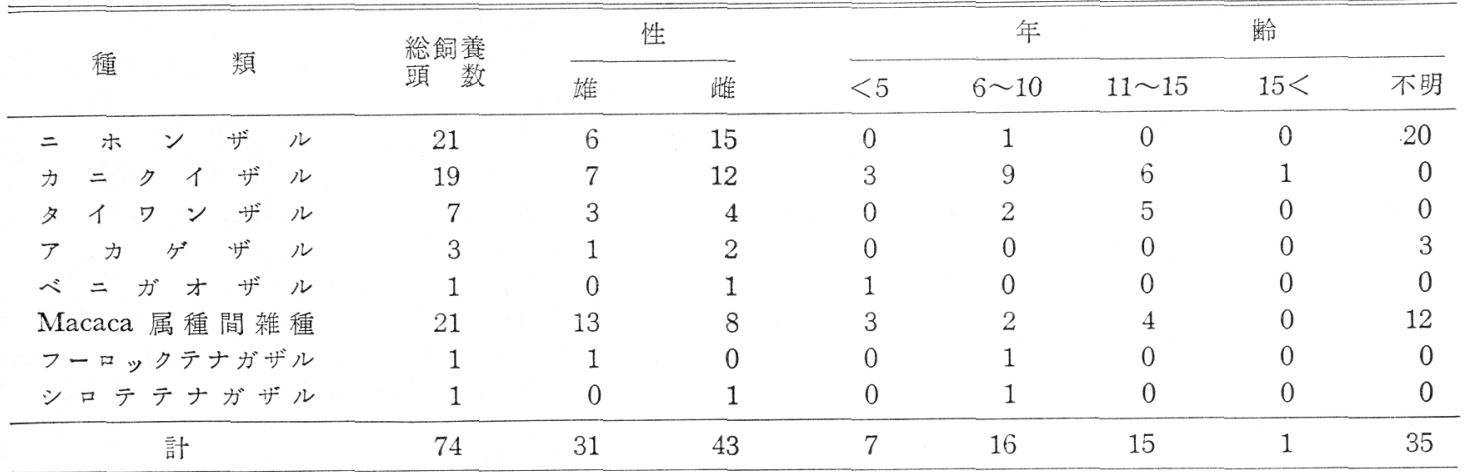


神奈川県下に飼養されているサルの䔬便検查成績

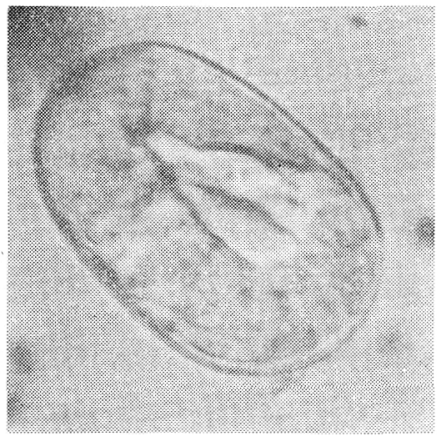

写真 2 粪線虫卵

表 3 蠕 虫検 查 成 績

\begin{tabular}{|c|c|c|c|}
\hline 飼 盖 形 態 & 䡯虫 & 糞線虫 & 混合感染 \\
\hline 個別飼盖 (24頭) & $1 / 24$ & $1 / 24$ & $1 / 24$ \\
\hline 群 飼 盖 (6 群) & $5 / 6$ & $4 / 6$ & $4 / 6$ \\
\hline
\end{tabular}

が検出された，この糞便を濾紙培養したところ，Strongyloides 属のフィラリア型子虫䄦よびラブディティス 型の雌成虫之雄成虫が得られたことから，本含子虫畉は 糞線虫卵であることが明らかたなった。

また，展示用として群で飼養されている6 施設からは， 5 施設（ニホンザル，カニクイザル，タイワンザル，ア カゲザル，Macaca 属種間雑種）に鞭虫卵，4 施設（サ ルの種類は同上）に子虫を含を線虫卵が認められたが， この含子虫卵も濾紙培養によりすべて糞線虫卵であるこ とが確認された。な牧，粪線虫の寄生の認められた4施 設は，すべて鞭虫との混合感染であった（表 3 ）。

以上の霞虫の寄生が認められたサルの一部を剖検した 結果, 盲腸から Trichuris trichiura，小腸から Strongyloides ülleborniの虫体を得ることができた。

\section{3. 考察}

神奈川県下に飼養されているサルのらち，とくに観覽 者のための展示を目的として群で飼養されているものに 高率に鞭虫之糞線虫の寄生が認められたが，これらは， 田中ら (1962) 20) の虫卵による鑑別法と今回の剖検の結 果と艺考光合和せると，すべて Trichuris trichiura とStrongyloides fülleborni と思われる.

この成績を野生のサル $6,8,12,16,18,21,22,25)$ 岁るいは輸入

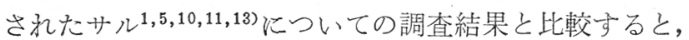
検出された蠕虫の種類が鞭虫之翼線虫の 2 種の久ときわ めて少なく, 青森県下北半島に持将るニホンザルの寄生 蠕虫相 ${ }^{18)}$ に類似している。しかしながら，神奈川県の気 候は寒冷とはいいがたく，寄生蠕虫相が昰しいことの原 因としては，気候的要因といらょりは，完しろ，飼盖下 といら特殊な条件を考光ない。すなわち，長期間飼養さ れたり，飼湌下で繁殖したりしていくうちに，次第に寄
生蠕虫相がそしくなっていき，T.trichiura と S. fülleborni が残って維持されているのであるら。

ところで，今回の結果では，個別に飼養されているも のでは 24 頭中 1 頭に鞭虫之䔬線虫の混合感染がみられ たのみで㞫が，群として飼養されているものでは 6 群 中 5 群に感染が認められた。これは，群として多数のサ ルが同居していると，比較的容易に寄生虫感染の維持が なされていることを推察させるものでめる。

今回の調查では, Shigella および Salmonella はまっ たく検出されず，寄生蠕虫も鞭虫（T. trichiura） と䔬線 虫 (S. fülleborni) の 2 種が認められたにすぎないが，T. trichiura は人体寄生の鞭虫と亡ったく同一種であり，ま

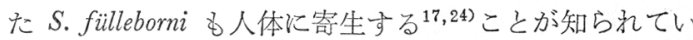
るので, サル類を飼養管理するには十分な注意を払ら必 要があろう.とくに，観覽者のための展示用として飼盖 されているサルにきわめて高率にこれらの寄生虫の感染 が認められたことは，公衆衛生上の問題が大きいと思わ れる。

〔本諭文の要旨は第 95 回日本獣医学会に拈いて発表し た.]

$$
\text { 文献 }
$$

1) 浅野和仁, 影井昇, 真弓 忠: 寄生虫誌, 27 , 増 47 (1978).

2) Hayama, S. and Nigi, H.: Primates, 4 (1) 97 112 (1963).

3) 本庄重男：モダンメディア，25，428４33 (1979).

4) 本庄重男: 公鼻衛生, 44, 433 438 (1980).

5) Honjo, S., Muto, K., Fujiwara, T., et al.: Jap. J. M. Sc. \& Biol., 16, $217 \sim 224$ (1963).

6) Horit, Y., Imada, I., Yanagida, T., et al.: Primates, 23, 416 431 (1982).

7) 一色於夢四郎, 野田亮二, 富岡長吉: 寄生虫誌, 4, 217 (1955).

8) 影井 昇, 長谷川久則：公衛院研報, 23, 234 238 (1974).

9) 菊池 滋, 林 滋生 : 寄生虫誌, 23, 増 44 (1974).

10) 小山 力, 熊田三由, 本多武, 济か: 寄生虫誌, 25, 増 83 (1976).

11) 小山 力, 志賀正男, 熊田三由, ほか：寄生虫誌, 24, 增 70 (1975).

12) 町田昌昭, 佐納南加子: 寄生虫誌, 23, 增 77 (1974).

13）森田 斌: 動水誌, 9, 53〜 55 (1967).

14) 牟田口利幸 : 野猿, No. 4, 11 13 (1959).

15) 中川志郎, 增井光子, 田辺與記, ほか：動水誌, 9, 112 114 (1967).

16) 和 秀雄, 松林清明, 町田昌昭: 生理生態, 16, 35 46 (1975).

17) Pampiglione, S. and Ricciardi, M. L.: Lancet, No. 7752, 663 665 (1972).

18) 高田伸弘, 黄 文雄, 藤田博已: 弘前医学, 33, $67 \sim 76$ (1981). 
19）高阪精夫：厚生の指標， 27 (12) 16～26 (1980).

20)田中 寬, 福井正信, 山本 久, 注: 実験動物, 11, 111 116 (1962).

21)田中利男, 和 秀雄 : 高崎山の野生ニホンザル 餌さづけ 10 年目の総合調査報告, 伊谷純一郎, 池田次郎, 田中利男編, 152 165, 勁草書房, 東 京 (1964).
22) Tanaka, T. and Nigi, H.: Primates, $8,91 \sim 106$ (1967).

23) Tanaka, Y. and Katsube, Y.: Jpn. J. Vet. Sci., 43, 787 789 (1981).

24）富田 勸：台湾医会誌，39，1884～1885 (1940).

25) 薄井万平, 堀井洋一郎: 宮大農報, $29,269 \sim 274$ (1982).

\title{
各地の種鷄群に拈ける Mycoplasma gallisepticum および
}

\section{M. synoviae の污染実態と分離株の薬剤感受性}

\author{
原田良昭* 内田幸治* 平元清和*
}

（昭和 58 年 10 月 21 日受理）

\begin{abstract}
Mycoplasma gallisepticum and M. synoviae in Breeding Flocks and Drug Sensitivity of Their Field Isolates Yoshiaki Harada (Agricultural Technical Center, Pfizer-Taito Co., Ltd., Kannami, Shizuoka 419-01) et al.
\end{abstract}

\section{SUMMARY}

Mycoplasma gallisepticum (MG) and $M$. synoviae (MS) infection were examined in 157 flocks, which consisted of 60 egg-type breeder flocks (E) on 20 farms in 16 prefectures and 97 meat-type breeder flocks (M) on 43 farms in 21 prefectures, over a period of 1978 through 1982.

At 60 weeks of age, MG- and MS-positive percentage were $55 \%$ and $73.3 \%$, respectively in $\mathrm{E}$ and $67 \%$ and $74.2 \%$ in M. MG- and MS-free flocks were converted frequently to be serologically positive by 20 to 30 weeks of age. The MG strains isolated were highly sensitive to DOTC, OTC, TC and PZ, but 26\% (9/35) of them were resistant to EM, OM, SP and TS. The MS strains isolated were also highly sensitive to DOTC, OTC, TC and TS, but poorly sensitive to the other drugs. It was suggested that the medication of tetracycline antibiotics might be required for MG and MS elimination.

要約

1978 年から 1982 年の 5 年間に慨付した各地の採卵種鷄 60 群 (16 道府県 20 農場), ブロイラー 種鶏 97 群（21 県 43 農場）の MG 拈よび MS に対する血清抗体を調査した. 検查は急速凝集反 応 (RST) で実施し，RST 陽性検体は血球凝集抑制反応で確認し陽性群を判断した. また一部の陽 生鷄から Mycoplasma を分離し, それらに対する各種薬剤（使用薬剤 TC, OTC, DOTC, EM, $\mathrm{OM}, \mathrm{SP}, \mathrm{TS}, \mathrm{CP}, \mathrm{SPE}, \mathrm{DSM}, \mathrm{KM}, \mathrm{NM}, \mathrm{CL}, \mathrm{PZ}$ の 14 種）の最小発育阻止濃度を寒天平板希釈 法で測定した.

1）血清抗体調査結果：MG 予よび MS は全国の種䳕群に蔓延し，20〜30 週齢前後に陽転が多 く認められた。 また 60 週齢時の陽性率をみると，採卵種鶏では MG 55\%，MS 73.3\%，ブロイラ 一種鶏は MG 67\%, MS 74.2\%であった. 両種とも MGより MS の感染群が多かった.

2）薬剤感受性試験の結果 : 両菌種とも TC 系薬剤には高い感受性を示した. とくに MGはマ クロライド系 (EM, OM, SP, TS) 薬剤に対し 2 峰性の感受性パターンを示し, 35 株中 9 株 (25.7 \%) に耐性が認められた. しかし，MSではTSを除くマクロライド系薬剤に感受性が低かった.

* 台糖ファイザー (株)・農産技術センター（静岡県田方郡函南町平井字五本松） 